\title{
FACTORS AFFECTING SMALL-SCALE SUGARCANE PRODUCTION IN NKOMAZI LOCAL MUNICIPALITY IN MPUMALANGA PROVINCE, SOUTH AFRICA
}

\author{
Metiso, H. ${ }^{1}$ and Tsvakirai, C. Z. ${ }^{2}$ \\ Correspondence author: H. Metiso. Email: metisohappyness@ gmail.com
}

\begin{abstract}
As the South African government forges ahead with its plans for land redistribution, there have been questions raised around factors that currently affect smallholder farmers' productivity as a means of preparing for the perceived future increase in farmer numbers. Answering these questions is critical for the sugarcane industry that holds a strategic value in South Africa. The present study uses Nkomazi Local Municipality, a prominent sugarcane production area, as a case study to answer some of these questions. The yield and socio-economic characteristics of 127 small-scale sugarcane farmers from the area were collected during one-on-one interviews and the former variable regressed against the later using the Cobb-Douglas production function. The average farmer in the sample produced 201 tonnes of sugarcane, on six hectares of land, applied $13.4 \mathrm{~kg}$ of fertilizer per hectare and employed seven labourers. The results of the regression analysis revealed the age of the farmer, farm size, fertilizer quantity, Land Bank's credit provision, the use of sprinkler irrigation, and land ownership significantly affected the yield of respondents. In light of the findings, the study recommends that efforts be increased to provide the production inputs (fertilizer and land), affordable credit, and advanced and affordable technological inputs as these were found to increase output. Furthermore, the study recommends that farmers' access to credit be increased in order to increase their agricultural output.
\end{abstract}

\section{Keywords: Cobb-Douglas production function, Productivity, South Africa}

\section{INTRODUCTION}

The sugar production industry is one of the most important industries in the whole world. Its importance is seen in many protectionist policies that have been established across borders of different countries. According to the South African Sugar Association (SASA, 2019), South Africa is cost competitive and tiers amongst the top 15 high quality sugar producers out of 120 global producers. The industry produces an average of 2.3 million tonnes of sugar per year (Department of Agriculture, Forestry and Fisheries (DAFF), 2016). This equates to 50\% of field crop gross farming income across the Mpumalanga and KwaZulu-Natal provinces (SASA, 2019). The industry produces an estimated average of 20 million tonnes of sugarcane per season and about $75 \%$ of this sugar is marketed in the Southern African Customs Union (SACU) region (DAFF, 2016). South Africa's sugar industry generates an average annual income of R12 billion from the SACU region sales and the export market (DAFF, 2016). On the local platform, the industry provides sustainable livelihoods for over $2 \%$ of South Africans

\footnotetext{
1 Post-graduate student, Department of Agricultural Economics and Extension, North-West University, Mafikeng South Africa, Email: metisohappyness@ gmail.com

2 Lecturer, School of Agricultural Sciences, Mpumalanga University, Mbombela, South Africa, Email: chichitsvakirai@gmail.com
} 
(DAFF, 2016). The sugar industry is a major contributor to the total agricultural workforce in the country. According to SASA (2019), it provided up to 85000 workers with direct employment (production and processing) and indirectly (input suppliers) employs up to 350000 workers.

Despite positive indicators of the industry's activities, South Africa's sugarcane production industry has been experiencing chronic yield decreases (Dubb, 2013). The negative output trend has been attributed to a number of different factors such as high input cost, limited use and availability of recommended technologies, droughts, unstable global economy, poor infrastructure and social challenges (Girei \& Giroh, 2012). The combined effects of these factors led to a steep decline in small-scale sugarcane growers from a former peak of 50000 to lower than 13044 between the early 2000s and 2011 (Dubb, 2013). Between the 2014/15 and $2015 / 16$ production periods alone, the industry experienced a $12.7 \%$ drop in yield due to drought (SASA, 2019). The enduring production woes threatened farming productivity, processors' profitability, as well as the livelihoods of households that depend on the industry.

Due to the value of the sugar industry and the pivotal role of smallholder agriculture, government has extended agricultural assistance (financial grants, equipment and farming implements, and extension services) to aid in addressing the challenges faced by sugarcane producers. Despite the government's efforts, the small-scale sugarcane producers are still facing challenges in improving their production levels. This study is aimed at investigating the factors that affect the farmers the most in Nkomazi Local Municipality, one of the main sugarcane production regions. It was envisaged that a detailed assessment of the challenges faced by farmers would provide knowledge for more effective government intervention. The research also seeks to identify the factors of production that would yield the highest productivity gains in the event of their increased employment. This objective is relevant in the current situation where the government aims to not only increase production and intensification, but to also increase the land available to formerly disadvantaged societal groups and smallholder farmers.

\section{ANALYTICAL PROCEDURE}

\subsection{Study area and population}

The study was conducted in Nkomazi Local Municipality in Mpumalanga Province, South Africa (Figure 1). Nkomazi Municipality is located in the eastern part of Ehlanzeni District. The municipality is linked to Swaziland by two provincial roads and by railway line and the main national road (N4) to Mozambique which forms the Maputo corridor (Nkomazi Municipality, 2006). According to City Population (2016), the municipality covers a surface area of $4786.7 \mathrm{~km}^{2}$, with a population size of 410907 , where $1.6 \%$ are white and $97.7 \%$ are black. Furthermore, $47.3 \%$ of this population are male and $52.7 \%$ are female (City Population, 2016). 


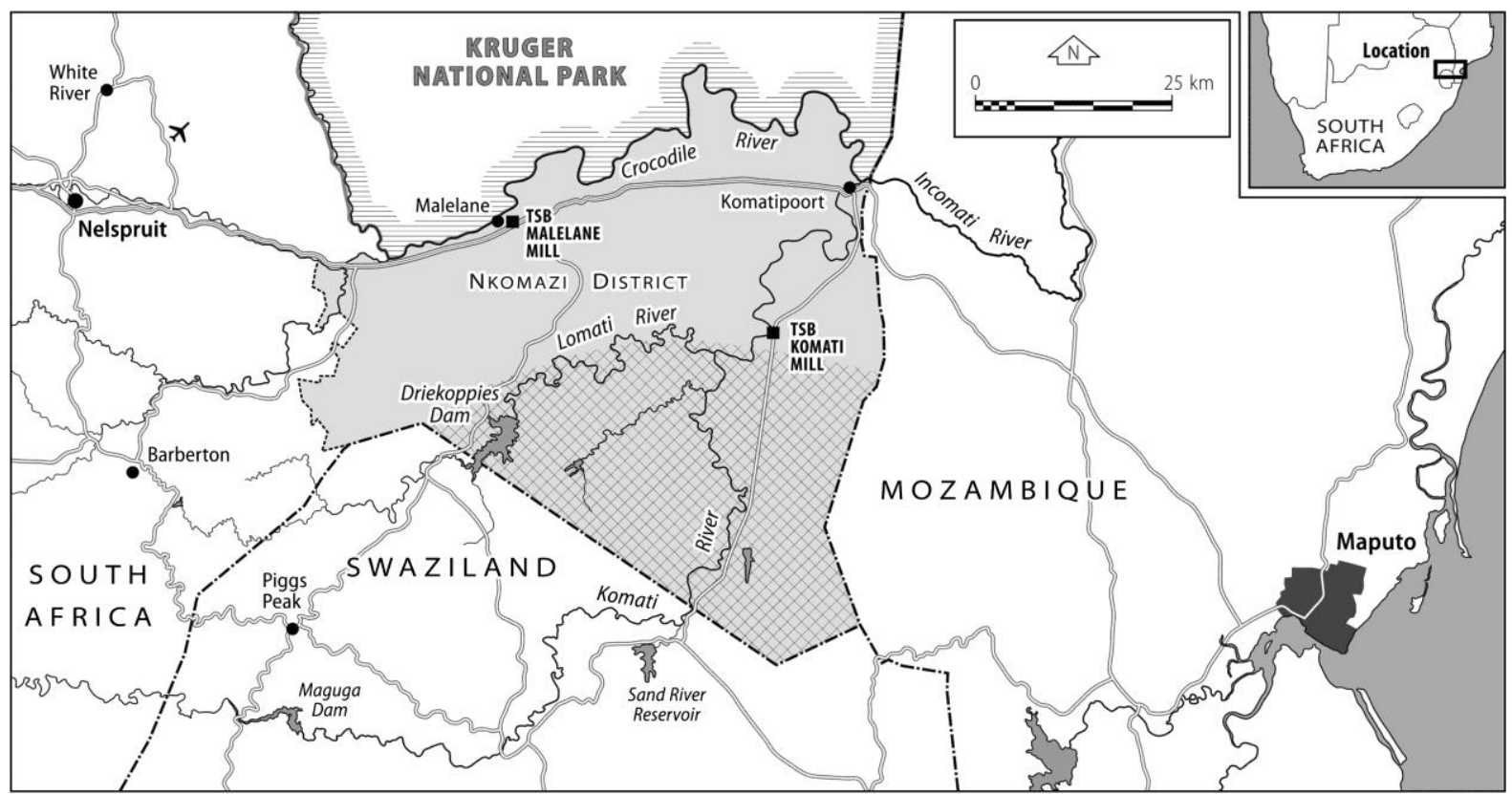

Figure 1: Map of Nkomazi local municipality

Source: James and Woodhouse (2017)

\subsection{Sample size and sampling procedure}

This study targeted small-scale sugarcane producers in Nkomazi Local Municipality; that is farmers producing on less than 18 hectares of land. A total of 1243 farmers met this criterion in the study area (Thabethe, 2014). A random sampling method was used to select a representative sample of the small-scale sugarcane farmers in Nkomazi Local Municipality. The random sampling method was chosen because it ensures that each individual is chosen entirely by chance and each member of the population has an equal chance of being included in the sample (Owino, Odondo \& Obange, 2018). The Raosoft scientific calculator was set to include a margin of error of $10 \%$ with confidence interval of $99 \%$. A sample of 147 was calculated, however, only 127 correctly complete questionnaires which were used for the study.

\subsection{Data collection}

This study used primary data collected through one-on-one interviews. A structured questionnaire was used to obtain information on farmers' production inputs use and the socioeconomic characteristics of the farmers. Questionnaires were structured into section A which captured socio-economic characteristics, section B which captured information on labour and land utilisation, and section $\mathrm{C}$ which captured information on farm operations. The questionnaires were prepared in English and translation was made available to respondents that did not understand the language very well. Data were collected from July to August 2018. Each interview took approximately 10 minutes to complete. Ethical clearance was granted by the North West University.

\subsection{Method of data analysis}

The relationship between sugarcane yield and the socio-economic and production factors was modelled using the production function. The Cobb-Douglas functional form was utilised as it 
provides an adequate representation and reflects the relationship between its inputs and the amount of output produced. The model took the form as represented in equation 1.

In $Y_{i}=\beta_{0}+\beta_{x} \sum \operatorname{In} X_{i n}+u_{i}$

Where: $Y_{i}=$ total output quantity of sugarcane

$X_{\text {in }}=$ independent variables

$u_{i}=$ error term

$\beta_{0}=$ parameters to be estimated

$\beta$ is the elasticities of production with respect to production inputs

The multinomial regression model was run using STATA version 12.

\section{RESULTS AND DISCUSSION}

\subsection{Descriptive statistics}

Most of the farmers that were interviewed were female (59\%), married (77\%), and had received some formal education (95\%). The average household in the sample had nine individuals and had a household-head who was about 58 years old. Half $(50 \%)$ of the interviewed farmers owned the land they farmed and the majority of the farmers $(48 \%)$ used micro-finance services provided by Akwanze. Most farmers used modern irrigation systems (48.8\% drip irrigation and $40.9 \%$ sprinkler irrigation) as opposed to the flood irrigation. A typical farmer produced 201 tonnes of sugarcane on 6 ha of land and applied $13.4 \mathrm{~kg}$ of fertilizer in one season and employed seven labourers.

\subsection{Empirical findings}

Table 1 displays the results of the multinomial regression analysis which was performed to analyse the factors that affect production of small-scale sugarcane. Ten explanatory variables were included in the model. Results from the regression model indicate that seven of the variables (marital status, farm size, age, fertilizer, source of agricultural credit, family labour, and remittances) had a statistically significant influence on the sugarcane production levels of the interviewed small-scale farmers.

Robust standard errors were used to control heteroscedasticity with the purpose of ensuring robust estimates. Reliability tests were run to measure the goodness of fit, multicollinearity and the joint variation of the explanatory variables on the estimated model. As shown in Table 1, the model had an F-statistic p-value of 0.000 which indicates a very good measure of fit. This implies that joint variation in explanatory variables included in the model explained the variation in the dependent variable to a great extent. VIF mean value of 1.14 was acquired and this value shows that the model was free of multicollinearity between the explanatory variables. The p-value test was used to determine the effect of each explanatory variable and major findings drawn from the analysis are discussed below. 
Table 1: Regression results

\begin{tabular}{|c|c|c|c|c|c|c|}
\hline \multirow[t]{2}{*}{ Variables } & \multirow[t]{2}{*}{ Coefficient } & \multirow[t]{2}{*}{ P value } & \multirow{2}{*}{$\begin{array}{l}\text { Robust } \\
\text { Standard } \\
\text { Estimates }\end{array}$} & \multirow[t]{2}{*}{ VIF } & \multicolumn{2}{|c|}{ Marginal values } \\
\hline & & & & & $\partial \mathbf{y} / \partial \mathbf{x}$ & $\begin{array}{l}\text { Standard } \\
\text { Estimates }\end{array}$ \\
\hline lnFarmSize & 0.428 & $0.000 * * *$ & 0.113 & 1.17 & 0.4017 & 0.1159 \\
\hline Age & 0.916 & $\mathbf{0 . 0 3 8}^{* *}$ & 0.437 & 1.11 & 0.7796 & 0.4158 \\
\hline lnFertilizer & 0.259 & $0.018 * *$ & 0.108 & 1.10 & 0.2875 & 0.1108 \\
\hline Land bank & 0.647 & $0.003 * *$ & 0.210 & 1.11 & 0.6865 & 0.2033 \\
\hline Remittance & 0.503 & $0.007 * *$ & 0.184 & 1.10 & 0.4860 & 0.1719 \\
\hline Lease & -0.416 & $0.050 * *$ & 0.211 & 1.14 & -0.4009 & 0.2172 \\
\hline Marital status & -0.169 & 0.305 & 0.165 & 1.08 & -0.1549 & 0.1616 \\
\hline $\begin{array}{l}\text { Irrigation hired } \\
\text { labour }\end{array}$ & 0.723 & 0.690 & 0.181 & 1.21 & -0.2343 & 0.1544 \\
\hline $\begin{array}{l}\text { Harvesting } \\
\text { family labour }\end{array}$ & -0.450 & $0.051 * *$ & 0.228 & 1.12 & -0.4601 & 0.2212 \\
\hline Sprinkler & 0.305 & $0.083 * *$ & 0.175 & 1.28 & 0.3053 & 0.1617 \\
\hline Constant & 0.734 & 0.683 & 1.795 & & 0.4017 & 0.1159 \\
\hline $\begin{array}{l}\text { F statistic } \\
\text { p-value }\end{array}$ & \multicolumn{6}{|l|}{0.000} \\
\hline VIF mean & \multicolumn{6}{|l|}{1.14} \\
\hline R-squared & \multicolumn{6}{|l|}{0.3034} \\
\hline
\end{tabular}

Source: Field survey (2018)

Results presented in Table 1 indicate that farm size of respondents had a statistically significant ( $p$-value $=0.000)$ and positive influence on sugarcane production output. This finding is in line with the results found by Baiyegunhi and Arnold (2011), as well as Thabethe (2014), which indicated that increasing the land size has a significant and positive impact on agricultural output. As another factor that is in line with prior expectations, the farmers' age had a statistically significant ( $\mathrm{p}$-value $=0.038$ ) and positive influence on sugarcane production output. The coefficient of the farmers' age implies that as a farmer grows older, he/ she will become more productive. These results are in line with the findings obtained by Kabwe (2012) who found that older farmers have more knowledge on production and have established the necessary contacts which enable them to do their business more productively than younger farmers.

In concurrence with the findings of Baiyegunhi and Arnold (2011) and Owino et al (2018), the quantity of fertilizer applied by respondents had a positive and statistically significant ( $\mathrm{p}$-value $=0.018$ ) influence on sugarcane production output. Fertilizer is used for improving productivity and in the intensification of agricultural production as a whole. It also plays a large role in regions where the scarcity of farmland is a problem. The results also show that access to agricultural credit directly from Land Bank had a positive statistically significant (p-value = 0.003) influence on the production output of small-scale sugarcane. Farmers who had obtained their agricultural credit from Land Bank were more likely to increase their productivity as compared to farmers that received credit from other sources. This might be because of the low interest rate that the Land Bank offers. Lower interest often lowers the cost of production and 
this means that the farmers are more likely to use their money productively as they will use less of it to service debts.

The farmers who received additional funds through remittances were more likely to produce efficiently as compared to farmers that did not receive this. These findings are in line with those acquired by Baloyi (2011) which showed that financial resources play a significant role in efficient production since sugarcane production often uses hired labour, irrigation equipment and hired tractors which need to be paid for. Receiving alternative sources of funds also means that the farmer is able to purchase the required farming implements at a time that is not dictated by the production season, which removes the seasonality constraints experienced in farming.

The results presented in Table 1 show that the use of the sprinkler irrigation method was positively statistically significant in influencing sugarcane production levels of small-scale sugarcane producers. This was found to be significant at the $10 \%$ level of probability reflecting a $90 \%$ level of confidence. As shown by the results, farmers that use this method were 0.305 times more likely to experience an increase in output as compared to those who received the drip and flood irrigation systems. The reason for this finding is that the method strikes a balance between costs and efficiency as it is relatively cheaper compared to drip irrigation and watersaving compared to the flood irrigation method.

The use of family labour for harvesting was found to be statistically significant at the $5 \%$ level of probability and negatively correlated with the dependent variable. This result means that the higher the number of family members used for harvesting, the lower the sugarcane output attained. This may be due to the fact that family members often slacken at the task as they are not adequately compensated for their work when compared to hired labour. The results show that farmers who use family labour to harvest their produce were 0.450 less likely to increase their production compared to those who used hired harvesting labour. This finding is in line with that of Baloyi (2011) who also found that the use of family labour can reduce labour costs, but it can have a negative impact on output at the end of production season.

Results show that the variable "leasing a farm" had a negative correlation with agricultural output. This was statistically significant at the 5\% level of probability reflecting a $95 \%$ level of confidence $(\mathrm{P}=0.050)$. It means that farmers who had a farming lease did not perform as well as those who had title deeds to their farms. Such results may be because farmers with property rights are able to make long-term fixed investments and are able to have a longer planning horizon as compared to farmers without farm ownership. These factors lead to better efficiency in farming, thus higher output.

\section{CONCLUSION AND RECOMMENDATIONS}

The study showed that factors affecting small-scale sugar production in Nkomazi Local Municipality were farmers' age, credit, fertilizer usage, farm size, labour, and agricultural assets. The study concludes that sugarcane production can be improved by employing more production inputs, securing farmers' property rights, and providing credit at an affordable interest rate. The study arrives at this conclusion because results revealed increase in agricultural input use has a great response to the farm output. Farm size had a significant influence on sugarcane production output, thus increasing the land size of farmers and provision of property right to land enhances output. Provision of access to credit with low interest rates can also increase farmers' output. 
The study recommends that farmers' access to credit be increased through provision of lower interest rates. Access to credit will help the farmers to increase their output. An example of such a facility is the Land Bank credit as it offers low interest rates. If farmers have access to low interest rate credit, they will be able to purchase more inputs such as fertilizer which have been identified as an input that can result in a positive impact on farm output. With access to credit, farmers will also be able to hire more labourers to help in the production process.

As increase in farm size was found to positively influence output, therefore consideration should be given to the allocation of larger farms to small-scale producers. In addition, farmers should be given property rights as this will assist them in making long-term decisions and investments which have a positive effect on the output. The study also recommends an increase in agricultural input use as the results showed that these inputs were elastic. It is envisaged that these efforts will result in the renewed growth of the Nkomazi Local Municipality's smallscale sugar production.

\section{REFERENCES}

BAIYEGUNHI, L.J.S. \& ARNORLD, C.A., 2011. Economics of sugarcane production on large scale farms in the Eshowe/Entumeni areas of KwaZulu-Natal, South Africa. Afr. $J$. Agric. Res., 6(21):4960-4967.

BALOYI, R.T., 2011. Technical efficiency in maize production by small-scale farmers in GaMothiba, Limpopo Province, South Africa. PhD Thesis, University of Limpopo.

CITY POPULATION, 2016. Nkomazi Local Municipality in South Africa. Available from: http://www.citypopulation.de/php/southafrica-admin.php?adm2id=MP324

DEPARTMENT OF AGRICULTURE, FORESTRY AND FISHERIES (DAFF), 2016. A profile of the South African sugar market value chain. Available from: http://www.nda.agric.za/doaDev/sideMenu/Marketing/Annualand20Publications/Com modityand20Profiles/fieldand20crops/Sugarand20Marketand20Valueand20Chainand20 Profileand202016.pdf

DUBB, A., 2013. The rise and decline of small-scale sugarcane production in South Africa: A historical perspective. J Agrar. Change, 16(4):518-542.

GIREI, A.A. \& GIROH, D.Y., 2012. Analysis of the factors affecting sugarcane (Saccharum officinarum) production under the out growers scheme in Numan Local Government Area Adamawa State, Nigeria. J. Educ. Pract., 3(8):195-201.

JAMES, P. \& WOODHOUSE, P., 2017. Crisis and differentiation among small-scale sugar cane growers in Nkomazi, South Africa. J. South Afr. Stud., 43(3):535-549.

KABWE, M., 2012. Assessing technical, allocative and economic efficiency of smallholder maize producers using the stochastic frontier approach in Chongwe District, Zambia. $\mathrm{PhD}$ Thesis, University of Pretoria.

NKOMAZI MUNICIPALITY, 2006. Nkomazi Local Municipality Integrated Development Plan (2006/2007). Available from: http://www.nkomazimun.co.za/PDFS/idp/idp\%202006-2007\%20exesum.pdf 
OWINO, O.E., ODONDO, A. \& OBANGE, N., 2018. Socio-economic determinants of sugarcane production among small-scale farmers in Nyando sugarbelt of Kenya. Int. $J$. Econ. Bus. Rev., 6(9):27-46.

SOUTH AFRICAN SUGAR ASSOCIATION (SASA), 2019. South African Sugar Industry Directory 2019/2020. Available from: https://sasa.org.za/custom_content/downloads/SASA-ID-2019-20.pdf

THABETHE, L.S., 2014. Estimation of technical, economic and allocative efficiencies in sugarcane production in South Africa: A case study of Mpumalanga growers. Afr. J. Econ. Sust. Develop., 5(16):86-96. 
